\title{
TRADITIONAL KNOWLEDGE OF FARMERS ON MEDICINAL PLANTS AND ITS ADOPTION IN MAMIT DISTRICT OF MIZORAM
}

\author{
C VANLALRUATA $^{1}$; Dr. JAHANARA ${ }^{2}$ \\ Msc Scholar, Professor and Head \\ Department of Agriculture Extension \&Communication \\ Sam Higginbottom University of Agricultural Technology \& Sciences, Prayagraj (211007) \\ DOI: 10.47856/ijaast.2021.v08i2.003
}

\begin{abstract}
Medicinal plants, also called medicinal herbs, have been discovered and used in traditional medicine practices since prehistoric times. Plants synthesise hundreds of chemical compounds for functions including defence against insects, fungi, diseases, and herbivorous mammals. Traditional healers have used several plants to treat various diseases over the years and use of many of these plants as medicine is described in Ayurvedic texts. Many diseases including cancer, leprosy, syphilis, all types of fever, children's abdominal disorders, elephantiasis and hydrocele have been treated using botanical sources. The plants synthesize several non-nutritive phytochemicals for different purposes and these have been reported to be beneficial as they possess various medicinal activities in humans. These phytochemicals are primary or secondary metabolites with varying biological activities and they are usually the main active principles present in plants. It has been estimated that in developed countries such as United States, plant drug constitute as much as $25 \%$ of the total drugs, while in fast developing countries such as India and China the contribution is as much as $80 \%$. Thus, the economic importance of medicinal plants is much more to India than to the rest of the world. These countries provide two third of the plants used in modern system of medicine and the health care system of rural population depend on the indigenous system of medicine. Hence the present study was undertake in order to find out the adoption level of the medicinal farmers towards improved variety and technology with respect to socio-economic profile of the farmers of Mamit block of Mamit District, Mizoram. The Study revealed that most of the respondents $(43.33 \%)$ per cent have medium adoption level followed by 28.34 per cent of respondents belonged to low Adopted category whereas 28.33 per cent fell in high adopted category.
\end{abstract}

KEYWORDS: Medicinal plants, Adoption level, Socio-economic profile. 


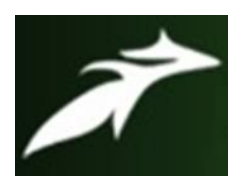

C VANLALRUATA et al, International Journal of Advances in Agricultural Science and Technology, Vol.8 Issue.2, February-2021, pg. 15-23

ISSN: 2348-1358

Impact Factor: 6.057

NAAS Rating: 3.77

\section{INTRODUCTION}

India is one of the richest floristic regions of the world and is well-known for its ancient heritage regarding medicinal plants and plants drugs. India has 16 agro-climatic zone, 45,000 different plants species, out of which 15,000 are medicinal. The estimated area under the medicinal crops in India is around two lakh hectares. Presently commercial cultivation of medicinal plant in India is restricted to few crops. The Indian system of medicine has identified 1.500 medicinal plants, of which 500 species are mostly used in preparation of drugs.

\section{HISTORY}

The earliest historical records of herbs are found from the Sumerian civilisation, where hundreds of medicinal plants including opium are listed on clay tablets. The Ebers Papyrus from ancient Egypt, c. 1550 BC, describes over 850 plant medicines. The Greek physician Dioscorides, who worked in the Roman army, documented over 1000 recipes for medicines using over 600 medicinal plants in De materia medica, c. $60 \mathrm{AD}$; this formed the basis of pharmacopoeias for some 1500 years. Drug research makes use of ethnobotany to search for pharmacologically active substances in nature, and has in this way discovered hundreds of useful compounds. These include the common drugs aspirin, digoxin, quinine, and opium. Therapeutic knowledge of Indian traditional medicine has propelled various traditional approaches with similar or different theories and methodologies, which are of regional significance. After independence, in 1951, planning commission took birth. Much later, in 1995, a different department called Department of Indian System of Medicine and Homoeopathy (ISM\&H) was molded. The acronym, AYUSH, which stands for Ayurveda, Yoga and Naturopathy, Unani, Siddha, and Homoeopathy was the new name of ISM\&H in 2003 as a detached Department under Ministry of Health and Family Welfare, Government of India.

\section{METHOD OF DATA COLLECTION}

Primary Data Collection: The primary data has been collected through survey and observation. Through schedule, data has been collected from the farmers of selected villages Schedule has been prepared with both close ended and open ended questionnaire. Secondary Data Collection: The secondary data has been collected through different source of materials, websites and other exiting records, various books, magazines, official records, research paper, internet, journals, news articles and other exiting sources of data.

\section{STATISTICAL ANALYSIS OF DATA}

Data collected were qualitative as well as quantitative. Qualitative data were converted into quantitative data. The quantitative data were tabulated on the basis of logical categorization 


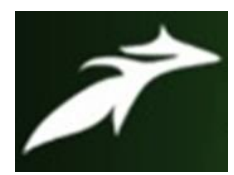

C VANLALRUATA et al, International Journal of Advances in Agricultural Science and Technology, Vol.8 Issue.2, February-2021, pg. 15-23

ISSN: 2348-1358

Impact Factor: 6.057

NAAS Rating: 3.77

method. Percentage, Coefficient correlation and Microsoft Excel were used for analysis purpose.

\section{RESULTS AND DISCUSSION}

Distribution of Socio-economic Profile Of the respondents

Table-1: Distribution of the respondents according to their Age

\begin{tabular}{|r|c|c|}
\hline S.I. No. & Age (years) & Percentage \\
\hline $\mathbf{1}$ & Young (25-35 years) & 30.83 \\
\hline $\mathbf{2}$ & Middle age (36-55) & 50 \\
\hline $\mathbf{3}$ & Old (above 55) & 19.16 \\
\hline & Total & $\mathbf{1 0 0}$ \\
\hline
\end{tabular}

It is seen in the table that 50 per cent of the respondents were of middle age group followed by young age group 30.83 per cent and old age group 19.16 per cent respectively.

Table-2: Distribution of the respondents according to their Religion.

\begin{tabular}{|c|c|c|}
\hline SI no. & Particulates & Percentage \\
\hline 1 & Hindu & 20 \\
\hline 2 & Christian & 80 \\
\hline & Total & $\mathbf{1 0 0}$ \\
\hline
\end{tabular}

The above table shows that 80 per cent respondents were Christian and 20 percent were Hindu and no other religion was found among them.

Table-3: Distribution of the respondents according to their Caste.

\begin{tabular}{|c|c|c|}
\hline SI no. & Particulates & Percentage \\
\hline 1 & OBC & 20 \\
\hline 2 & ST & 80 \\
\hline & Total & $\mathbf{1 0 0}$ \\
\hline
\end{tabular}

The above table shows that 80 percent respondents were ST and 20.83 percent respondent were $\mathrm{OBC}$ caste was found among them. 


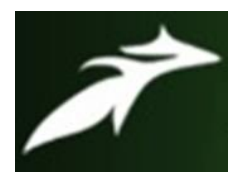

C VANLALRUATA et al, International Journal of Advances in Agricultural Science and Technology, Vol.8 Issue.2, February-2021, pg. 15-23

ISSN: 2348-1358

Impact Factor: 6.057

NAAS Rating: 3.77

Table-4: Distribution of the respondents according to their Educational attainment

\begin{tabular}{|l|l|c|}
\hline SI no. & Particulates & Percentage \\
\hline 1 & Illiterate & 10.83 \\
\hline 2 & Primary school & 13.33 \\
\hline 3 & Secondary school & 24.18 \\
\hline 4 & High school & 25 \\
\hline 5 & Intermediate & 14.16 \\
\hline 6 & Graduation/PG & 12.5 \\
\hline & Total & $\mathbf{1 0 0}$ \\
\hline
\end{tabular}

The above table shows that 14.16 percent respondents were Intermediate and 10.83 percent respondents were Illiterate and 25 percent respondents were High school and 24.18 percent respondents were secondary School and 13.33 percent respondents were Primary and 12.5 percent respondents were Graduation.

Table-5: Distribution of the respondents according to their Yearly income.

\begin{tabular}{|l|l|l|}
\hline SI no. & Particulates & Percentage \\
\hline 1 & Income Rs.30000-50000 & 45 \\
\hline 2 & Income Rs.50000-70000 & 34.16 \\
\hline 3 & Income Rs.70000-90000 & 20.83 \\
\hline & Total & $\mathbf{1 0 0}$ \\
\hline
\end{tabular}

It is clear from the above table that 45 per cent respondents have 30000-50000 income, 34.16 per cent respondents have between Rs. 500000 - 70000, and 20.83 per cent respondents have income between Rs. 70000 - 90000.

Table-6: Distribution of the respondents according to their Type of family.

\begin{tabular}{|c|c|c|}
\hline SI no. & Particulates & Percentage \\
\hline 1 & Nuclear family & 71.6 \\
\hline 2 & Joint family & 28.3 \\
\hline & Total & $\mathbf{1 0 0}$ \\
\hline
\end{tabular}




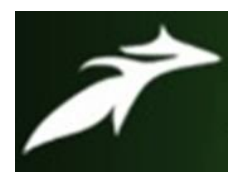

C VANLALRUATA et al, International Journal of Advances in Agricultural Science and Technology, Vol.8 Issue.2, February-2021, pg. 15-23

ISSN: 2348-1358

Impact Factor: 6.057

NAAS Rating: 3.77

The above table shows that 71.6 per cent respondents have nuclear family and other 28.3 per cent respondents have in joint family.

Table-7: Distribution of the respondents according to their Size of family

\begin{tabular}{|c|c|c|}
\hline SI no. & Particulates & Percentage \\
\hline 1 & Upto 5 members & 58.33 \\
\hline 2 & Above 5 members & 41.67 \\
\hline & Total & $\mathbf{1 0 0}$ \\
\hline
\end{tabular}

It is evident from the above table shows that 58.33 per cent of respondents had upto 5 members in the family whereas respondents 41.67 per cent respondents had Above 5 members in the family.

Table-8: Distribution of the respondents according to their Type of house.

\begin{tabular}{|c|c|c|}
\hline SI no. & Particulates & Percentage \\
\hline 1 & Hut & 12.5 \\
\hline 2 & Semi-cemented & 39.2 \\
\hline 3 & Cemented & 48.3 \\
\hline & Total & $\mathbf{1 0 0}$ \\
\hline
\end{tabular}

The above table reveals that 48.3 per cent respondents live in cemented house followed by 39.2 per cent respondents live in Semi-cemented house and 12.5 per cent respondents live in hut type of house

Table-9: Distribution of the respondents according to their Land holdings.

\begin{tabular}{|l|l|l|}
\hline SI no. & Particulates & Percentage \\
\hline 1 & Land size 2-3 acre. & 40.83 \\
\hline 2 & Land size 3.1- 4 acre. & 41.6 \\
\hline 3 & Land size above 4.1acre. & 17.5 \\
\hline & Total & $\mathbf{1 0 0}$ \\
\hline
\end{tabular}




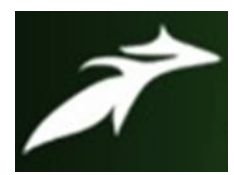

C VANLALRUATA et al, International Journal of Advances in Agricultural Science and Technology, Vol.8 Issue.2, February-2021, pg. 15-23

ISSN: 2348-1358

Impact Factor: 6.057

NAAS Rating: 3.77

It is evident from the above table shows that 17.5 per cent respondents were having above 4.1 acre of land, 41.6 per cent respondents were having 3.1-4 acre of land and 40.83 per cent were having 2-3 acre of land.

Table-10: Distribution of the respondents according to their Extension contacts.

\begin{tabular}{|c|c|c|}
\hline SI no. & Particulates & Percentage \\
\hline 1 & Low & 12.5 \\
\hline 2 & Medium & 56.7 \\
\hline 3 & High & 30.9 \\
\hline & Total & $\mathbf{1 0 0}$ \\
\hline
\end{tabular}

The data in the above table shows that most of the respondent 56.67 per cent were found in medium extension contacts category followed by high category 30.9 per cent and low 12.5 per cent extension contacts category respectively.

\section{ADOPTION LEVEL}

Table-11: Distribution of the respondents according to their Adoption level

\begin{tabular}{|l|c|c|c|}
\hline \multicolumn{1}{|c|}{ Technology } & \multicolumn{2}{|l|}{ Adoption level } \\
\cline { 2 - 4 } & $\begin{array}{c}\text { Fully Adopted } \\
\text { F. (\%) }\end{array}$ & $\begin{array}{c}\text { Partially } \\
\text { Adopted } \\
\text { F. (\%) }\end{array}$ & $\begin{array}{c}\text { Not Adopted } \\
\text { F. (\%) }\end{array}$ \\
\hline Soil testing and reclamation & 29 & 66 & 25 \\
& $(24.16)$ & $(55)$ & $(20.84)$ \\
Medicinal variety (Carica & 33 & 57 & 30 \\
papaya,etc) & $(27.5)$ & $(47.5)$ & $(25)$ \\
& & & \\
\hline Planting spacing & 43 & 60 & $(14.16)$ \\
\hline & $(35.83)$ & $(50)$ & \\
\hline
\end{tabular}




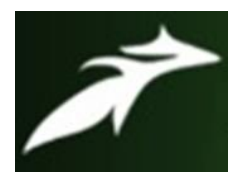

C VANLALRUATA et al, International Journal of Advances in Agricultural Science and Technology, Vol.8 Issue.2, February-2021, pg. 15-23

ISSN: 2348-1358

Impact Factor: 6.057 NAAS Rating: 3.77

\begin{tabular}{|c|c|c|c|}
\hline $\begin{array}{l}\text { Irrigation practices (Sprinkler, } \\
\text { etc) }\end{array}$ & $\begin{array}{c}51 \\
(42.5)\end{array}$ & $\begin{array}{c}43 \\
(35.84)\end{array}$ & $\begin{array}{c}26 \\
(21.66)\end{array}$ \\
\hline FYM application & $\begin{array}{c}53 \\
(44.16)\end{array}$ & $\begin{array}{c}44 \\
(36.67)\end{array}$ & $\begin{array}{c}23 \\
(19.17)\end{array}$ \\
\hline Green manuring & $\begin{array}{c}57 \\
(47.5)\end{array}$ & $\begin{array}{c}34 \\
(28.34)\end{array}$ & $\begin{array}{c}29 \\
(24.16)\end{array}$ \\
\hline Biofertilizers & $\begin{array}{c}39 \\
(32.5)\end{array}$ & $\begin{array}{c}45 \\
(37.5)\end{array}$ & $\begin{array}{c}36 \\
(30.00)\end{array}$ \\
\hline Chemical fertilizer $(\mathrm{Kg}) \mathrm{N}: \mathrm{P}: \mathrm{K}$ & $\begin{array}{c}34 \\
(28.34)\end{array}$ & $\begin{array}{c}39 \\
(32.5)\end{array}$ & $\begin{array}{c}47 \\
(39.16)\end{array}$ \\
\hline IPM for diseases & $\begin{array}{c}30 \\
(25.00)\end{array}$ & $\begin{array}{c}52 \\
(43.34)\end{array}$ & $\begin{array}{c}38 \\
(31.66)\end{array}$ \\
\hline IDM & $\begin{array}{c}27 \\
(22.5)\end{array}$ & $\begin{array}{c}58 \\
(48.34)\end{array}$ & $\begin{array}{c}35 \\
(29.16)\end{array}$ \\
\hline $\begin{array}{l}\text { Uses for Marketing/commercial } \\
\text { purpose }\end{array}$ & $\begin{array}{c}67 \\
(55.83)\end{array}$ & $\begin{array}{c}28 \\
(23.34)\end{array}$ & $\begin{array}{c}25 \\
(20.83)\end{array}$ \\
\hline Medicinal benefits & $\begin{array}{c}44 \\
(38.5)\end{array}$ & $\begin{array}{c}59 \\
(46.67)\end{array}$ & $\begin{array}{c}17 \\
(15.83)\end{array}$ \\
\hline $\begin{array}{l}\text { Knowledge about the therapeutic } \\
\text { application of the plants }\end{array}$ & $\begin{array}{c}37 \\
(30.83)\end{array}$ & $\begin{array}{c}49 \\
(40.83)\end{array}$ & $\begin{array}{c}34 \\
(28.34)\end{array}$ \\
\hline $\begin{array}{l}\text { Plant parts used for medicinal } \\
\text { purpose }\end{array}$ & $\begin{array}{c}38 \\
(31.66)\end{array}$ & $\begin{array}{c}42 \\
(35)\end{array}$ & $\begin{array}{c}40 \\
(33.34)\end{array}$ \\
\hline
\end{tabular}




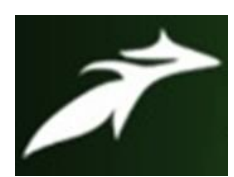

C VANLALRUATA et al, International Journal of Advances in Agricultural Science and Technology, Vol.8 Issue.2, February-2021, pg. 15-23

ISSN: 2348-1358

Impact Factor: 6.057

NAAS Rating: 3.77

Table-12: Distribution of respondents according to their overall Adoption level:

\begin{tabular}{|c|c|c|}
\hline S.N. & Adoption level & Percentage \\
\hline $\mathbf{1}$ & Low(14-23) & 28.34 \\
\hline $\mathbf{2}$ & Medium(24-33) & 43.33 \\
\hline $\mathbf{3}$ & High(34-42) & 28.33 \\
\hline $\mathbf{4}$ & Total & 100.00 \\
\hline
\end{tabular}

The data in table 4.3.2 showed that most of the respondents 43.33 per cent have medium adoption level followed by 28.34 per cent of respondents belonged to low Adopted category whereas 28.33 per cent fell in high adopted category.

Table-13: Relationship between socio-economic Characteristics and adoption level of medicinal plant farmers:

\begin{tabular}{|l|l|l|}
\hline Sl.No. & Characteristics & "r" value \\
\hline $\mathbf{1 .}$ & Age & $0.163 \mathrm{NS}$ \\
\hline $\mathbf{2 .}$ & Education & $0.295^{*}$ \\
\hline $\mathbf{3}$ & Occupation & $0.354^{*}$ \\
\hline $\mathbf{4}$ & Family size & $0.654^{*}$ \\
\hline $\mathbf{5}$ & Land holding & $0.035 \mathrm{NS}$ \\
\hline $\mathbf{6}$ & Annul income & $0.062 \mathrm{NS}$ \\
\hline $\mathbf{7}$ & Participation in Extension activities & $0.321^{*}$ \\
\hline & $*$ Significant at $\mathrm{p}=0.05, \mathrm{NS}=$ Non Significant & \\
\hline
\end{tabular}

The data from the above table shows that Education, Occupation, Family size and Extension activities are positively significant at $0.05 \%$ whereas Age, Land holdings and Annual income are positive but non-significant at $0.05 \%$ to extend of adoption of the respondent respectively.

\section{CONCLUSION}

It can be concluded that most of the respondents (43.33\%) had medium level of Adoption followed by low (28.34\%) and high (28.33\%) and the relationship between adoption level and socio- economic profile of respondents and Occupation $(0.354 *)$, Family size $(0.654 *)$ and Extension activities $(0.321 *)$ are positively significant at $0.05 \%$ whereas Age $(0.163 \mathrm{NS})$, Land holdings $(0.035 \mathrm{NS})$ and Annual income(0.062NS) are positive but non-significant at $0.05 \%$ to extend of adoption of the respondent respectively. Hence it is imperative that government and the experts should take more steps like training, field demonstration, more interaction with 


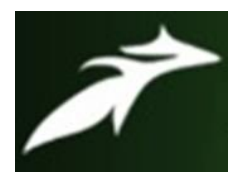

C VANLALRUATA et al, International Journal of Advances in Agricultural Science and Technology, Vol.8 Issue.2, February-2021, pg. 15-23

ISSN: 2348-1358

Impact Factor: 6.057

NAAS Rating: 3.77

the farmers, more government schemes, loans so that more people can adopt medicinal plants as it also generates lots of employment which will help in the upliftment of society.

\section{REFERENCES}

[1]. Zorinpuii Khiangte1 and $H$. Lalramnghinglova 2017. Inventorization of indigenous medicinal plants and practices in Mizoram, North East India (Department of Environmental Science, School of Earth Sciences and Natural Resources Management).

[2]. H. Lalramnghinglova 2016. Documentation of Medicinal Plants based on Traditional Practices in the IndoBurma Hotspots Region of Mizoram, North East India.

[3]. Dr. Gian Singh, Dr. H.B Singh, Dr. T.K Mukherjee 2003. Ethnomedicine Of North East India.

[4]. Rosangkima, G and Jagetia, GC 2015. In Vitro Anti-cancer Screening Of Medicinal Plants Of Mizoram State, India, Against Dalton's Lymphoma MCF-7 And Hela Cells.

[5]. Prabhat Kumar Rai and H. Lalramnghinglova 2010. Ethnomedicinal Plant Resources of Mizoram, India: Implication of Traditional Knowledge in Health Care System.

[6]. Hemanta Kumar Sharma, Lalrampari Chhangte, Ashoke Kumar Dolui. 2000 Traditional medicinal plants in Mizoram, India.

[7]. Garima Singh, Ajit Kumar Passari, Bhim Pratap Singh and N. Senthil Kumar 2017. Traditionally Used Medicinal Plants Belongs to Family Asteraceae for the Treatment of Cancer in Mizoram, Northeast India. 